\title{
SOME FEATURES IN THE FINNISH CLIMATE AFFECTING CEREAL HARVESTING
}

\author{
YRJÖ PESSI \\ Society of Peat Cultivation, Experimental Station Leteensuo
}

Received January 4, 1965 .

Owing to the change that has taken place in the harvesting of cereals with the adoption of combine harvesting instead of drying on poles, the late summer weather conditions have come to play an even more decisive part in the quality of the crops. When the cereals are dried on poles, the cutting may be done at a given stage of ripeness regardless of the moisture content of the grain. On the other hand it is considered a prerequisite of combine harvesting that the moisture content of the grain should be less than $25 \%$, and, with certain kinds of cereals, preferably below $20 \%$. Attainment of such low grain moisture values is not possible under all circumstances since it is dependent on a sufficiently low relative humidity of the air. ${ }^{1}$ At the same time the grains may lose their dormancy with a consequent risk of sprouting in the ear when the weather is rainy. In the following will be considered two features of our climate that are significant in the harvesting of cereals.

\section{Relative humidity of the air}

In Fig. 1 the monthly means of the relative humidity of air are presented for seven localities based on weather observations made by the Central Institute of Meteorology. It is evident from the monthly values that the relative humidity increases towards the autumn. In the right-hand column of the figure the monthly means of the observations made at 14.00 hours are shown separately. It can be seen that an even stronger increase of humidity towards the autumn is observable in the daytime

1 Hrrvola, S-L. 1958. Kokemuksia kevätvehnän leikkuupuinnista. Summary: Experiences concerning combine harvesting of spring wheat. Maat. ja koetoim. 12:82-91.

VALLE, O. 1958. Kokemuksia leikkuupuinnista Suomen oloissa. Summary: Use of combine harvesters in Finland. Ibid. 12:64-81. 


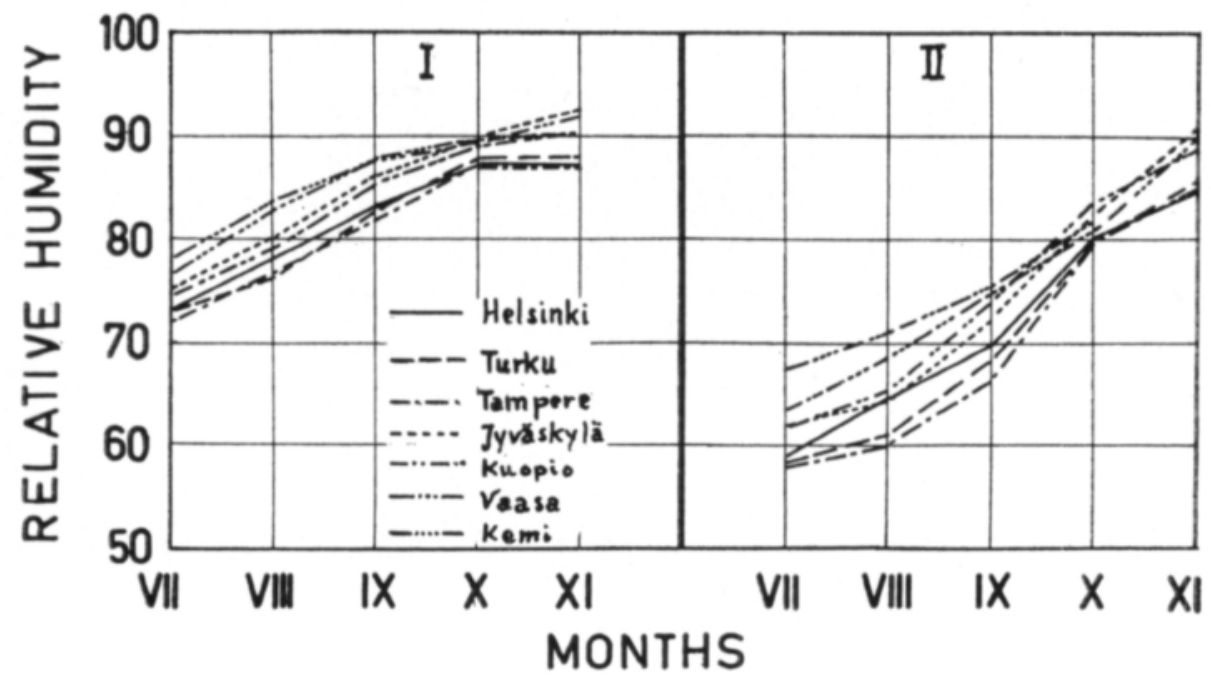

Fig. I Monthly means (I) of the relative humidity of the air in various localities and monthly means of the observations made at $\mathbf{1 4 0 0}$. hours (II). The monthly means have been calculated from observations made every three hours.

than is revealed by the monthly means of the entire 24-hour day. In addition, the distribution of relative humidity by calendar month is shown in Table 1 for some localities. The increasing relative humidity of the air with the progress of the autumn season is again reflected by these figures. It is thus evident that the weather-induced conditions for lowering the moisture content of the cereals in view of combine harvesting are the more favourable the earlier the ripening of the grain.

\section{Weather conditions conducive to sprouting in the ear}

The relative humidity of the air is a factor of significance not only as regards the variations in the moisture content of the grain, it also affects the sprouting of the grain in the ear. The increase of the relative humidity towards the autumn implies an increased possibility for sprouting in the ear. However, sprouting in the ear only occurs if, simultaneously with a sufficiently high relative humidity, the temperature requisite for sprouting prevails. At higher temperatures the sprouting takes place more rapidly, while it may also be encountered at lower temperatures provided that the period of high humidity is correspondingly prolonged. It should be noted that although the relative humidity of the air increases towards the autumn, it is accompanied by a drop in the temperature. It is therefore hard to draw any immediate inferences concerning the potential increase of the chances for sprouting in the ear with the progressing season. In the following an attempt is made to find out how far the climate-induced conditions causing sprouting in the ear are present in the same degree throughout the late part of the summer.

For the purposes of the study the observations of the Central Institute of Meteorology made at Helsinki (Ilmala), Vaasa and Kajaani during several decades were 


\begin{tabular}{|c|c|c|}
\hline \multirow{4}{*}{ 苞 } & $x$ & 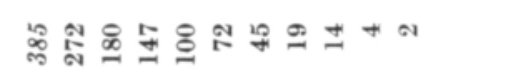 \\
\hline & $\ddot{x}$ & 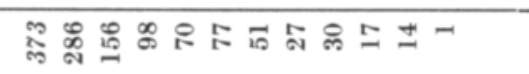 \\
\hline & $\Xi$ & 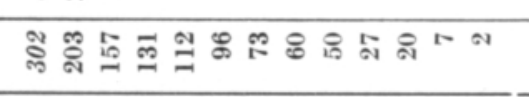 \\
\hline & $\overline{5}$ & 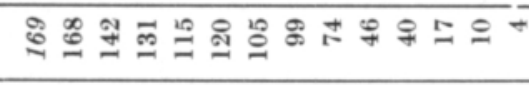 \\
\hline \multirow{4}{*}{ 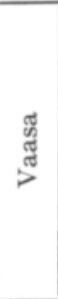 } & $x$ & 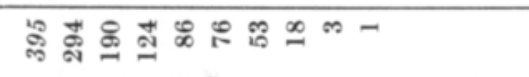 \\
\hline & $\stackrel{x}{a}$ & 承 \\
\hline & 5 & 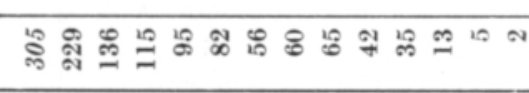 \\
\hline & 5 & 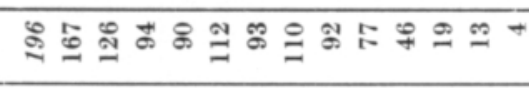 \\
\hline \multirow{4}{*}{ 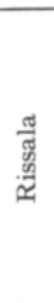 } & $x$ & 承 \\
\hline & 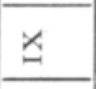 & 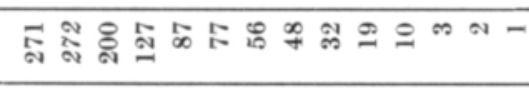 \\
\hline & E & 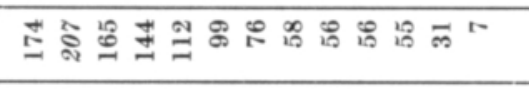 \\
\hline & I & 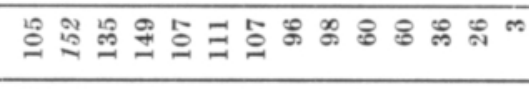 \\
\hline \multirow{4}{*}{ 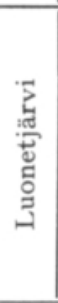 } & $x$ & 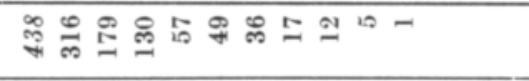 \\
\hline & $\ddot{\sim}$ & 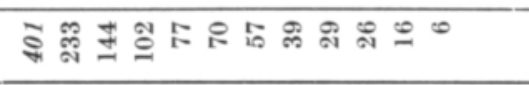 \\
\hline & $\exists$ & 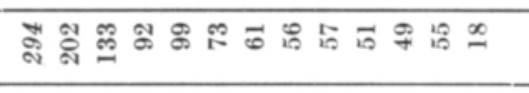 \\
\hline & 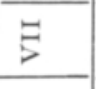 & 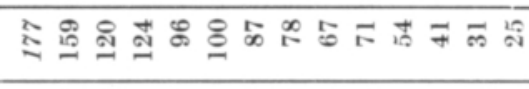 \\
\hline \multirow{4}{*}{ 总 } & $x$ & హี \\
\hline & $\stackrel{x}{2}$ & 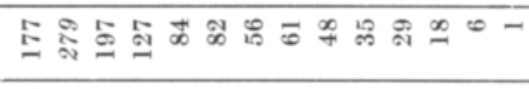 \\
\hline & $\Xi$ & 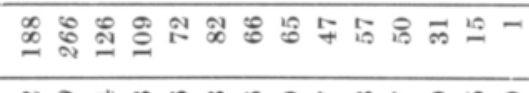 \\
\hline & 5 & 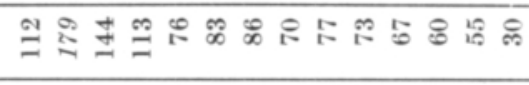 \\
\hline \multirow{4}{*}{ 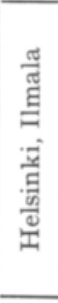 } & $x$ & 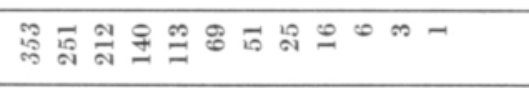 \\
\hline & $\ddot{z}$ & 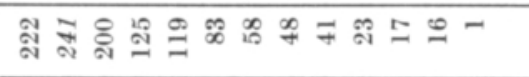 \\
\hline & 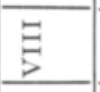 & 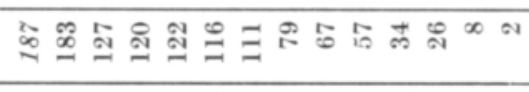 \\
\hline & 5 & 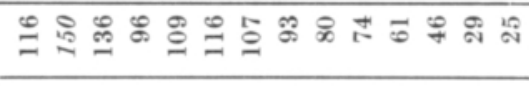 \\
\hline & $\circ$ & 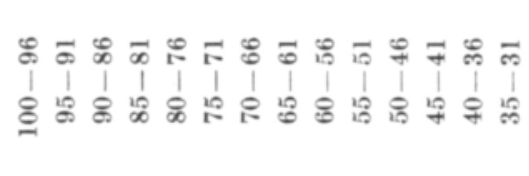 \\
\hline
\end{tabular}


examined in order to ascertain how often and at what times weather conditions existed in which sprouting in the ear would be possible. From these localities continuous series of observations covering long periods were available. In the final assessment concerning the different localities it was assumed that sprouting in the ear may occur when the weather conditions are such that the mean of the relative air humidity exceeds $88 \%$ and the temperature observations made at $8.00,14.00$ and 20.00 hours during a coincident period, when added, yield a sum in excess of $90^{\circ} \mathrm{C}$. Any weather condition consistent with these conditions shall be called in the following weather conditions conducive to sprouting in the ear.

The above-mentioned temperature sum was determined on the basis of germinating tests carried out in the laboratory and, partially, on the basis of observations made in the field. It should be noted that the temperature sum value is in itself not applicable to all kinds of cereals: germination of oats and of spring wheat requires a higher temperature sum than that of rye and multi-row barley. Germination of the two latter crops is possible already when the temperature sum of $90^{\circ} \mathrm{C}$ occurs.

It should be noted, on the other hand, that the stipulated relative humidity limit, $88 \%$, is not necessarily correct and that germinating in the ear may occur, e.g., at lower relative humidities of the air. However, this inexactitude is believed to be without significance in the present instance, because the purpose of the study is merely to compare the weather conditions at different times on the basis of a given point of reference, that is, to establish relative assessments.

A preliminary study was made with the observations from Ilmala, basing it on two different temperature sums, namely, $90^{\circ} \mathrm{C}$ and $110^{\circ} \mathrm{C}$, and on three relative humidity levels, 88,90 and $92 \%$. The results of this study can be seen in Table 2 . The

Table 2. The frequency of instances in which the relative humidity of the air at Ilmala was higher than 88,90 and $92 \%$, respectively, and the sum of the temperatures recorded at $8.00,14.00$ and 20.00 hours during the same period exceeded $90^{\circ} \mathrm{C}$ and $110^{\circ} \mathrm{C}$, respectively. The material consists of observations covering a period of 56 years.

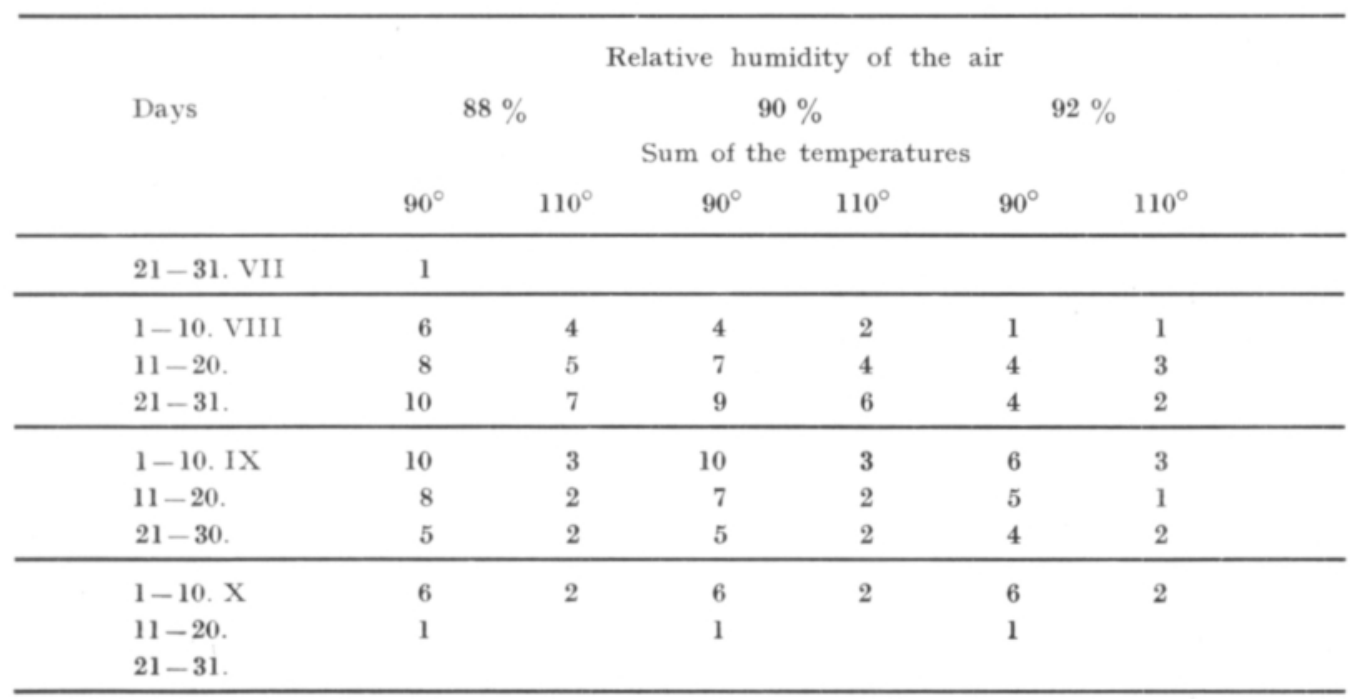




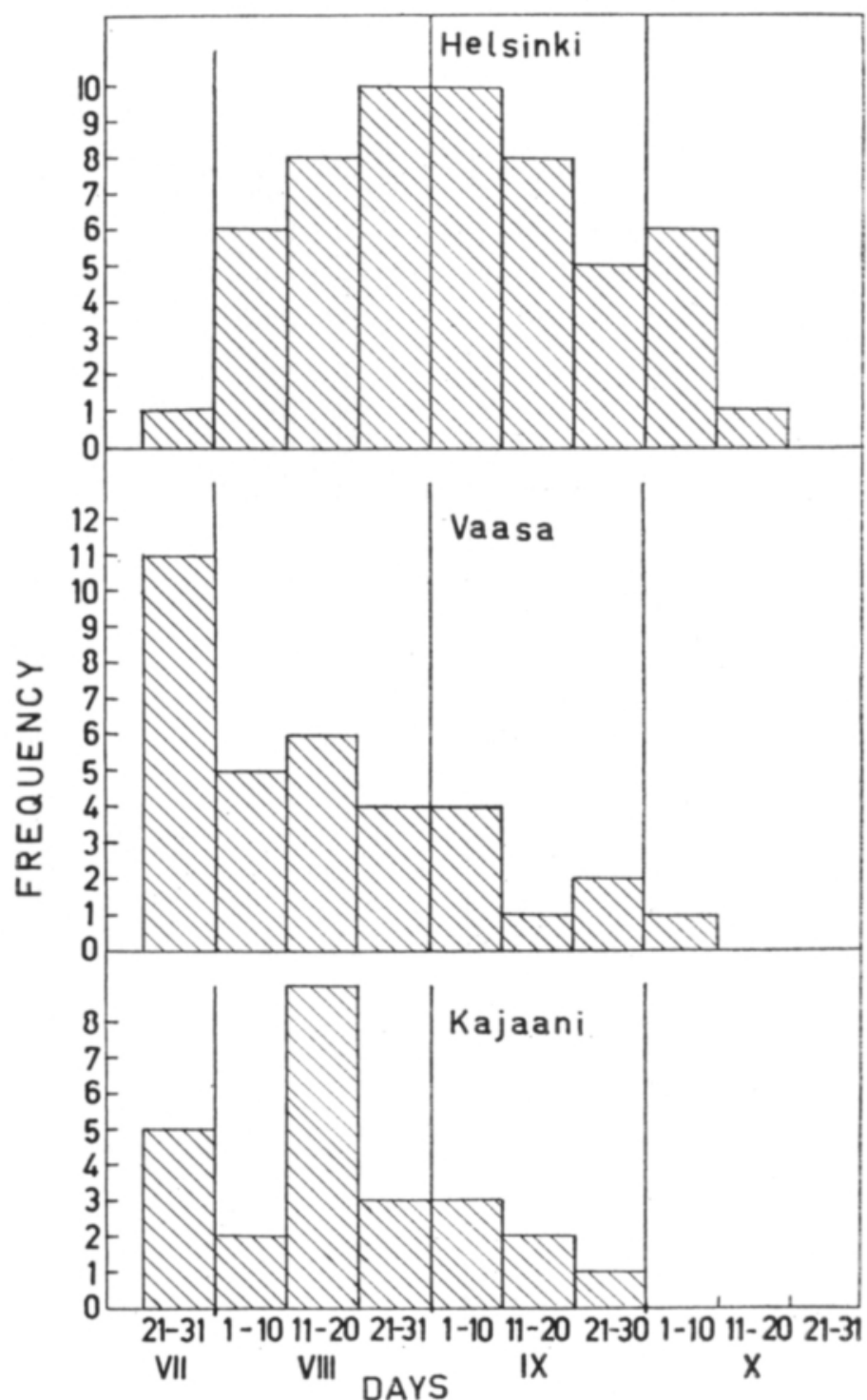

Fig. 2. The frequency rate of weather conditions conducive to sprouting in the ear during 56 years at Helsinki (Ilmala), Vaasa and Kajaani.

figures showing the frequency of the instances in which the weather conditions in question occurred reveal that they are commonest at Ilmala in August and September, irrespective of which combination of temperature sum and mean relative humidity of the air is employed as criterion. Weather conditions conducive to sprouting in the ear have occurred most frequently during the period between August 20th and September 10th.

The results compiled in Fig. 2 indicate that weather conditions conducive to sprouting in the ear rarely occur after the 10th of September in Vaasa and Kajaani. 
Considering the fact that in these regions the cereals seldom reach the stage of ripeness rendering sprouting in the ear possible during August, it can be concluded that sprouting in the ear is far less common than in the more southerly parts of the country.

\section{Conclusions}

On the basis of the present results the inference can be drawn that in Finland weather-induced prerequisites for a lowering of the moisture content of cereals to the desirable level for combine harvesting are the better the earlier the cereals ripen.

Weather conditions in which sprouting in the ear is possible occur most commonly during August and September. They are commonest in Helsinki during the period between August 20th and September 10th, although they are not decisively less prevalent at any other time during these months. In more northerly locations weather conditions conducive to sprouting in the ear are rare in the second half of September.

SELOSTUS

ERÄITÄ ILMASTOMME PIIRTEITÄ VILJAN KORJUUN KANNALTA

YRJö PESS:

Suoviljelysyhdistys, Leteensuon koeasema

Tutkimuksessa on tarkasteltu ilman suhteellista kosteutta loppukesän ja syksyn kuukausina. Lisäksi on tutkittu eri ajankohtien säätilaa siinä mielessä, että voitaisiin päätellä, ovatko edellytykset tăhkäidäntäăn kasvukauden eri aikoina erilaiset. Viimemainittu tarkastelu on suoritettu Helsingissã, Vaasassa ja Kajaanissa tehtyjen ilmatieteellisen keskuslaitoksen havaintojen perusteella 56 vuoden ajalta. Tarkastelussa on perustaksi otettu se, että tähkäidäntä on mahdollista sellaisessa säätilassa, jolloin ilman suhteellisen kosteuden keskiarvo on yli $88 \%$ ja samanaikaisen jakson klo 8, 14 ja 20 tehtyjen havaintojen lämpötilasumma yli $90^{\circ} \mathrm{C}$. Mainittuun lämpötilasummaan päädyttiin laboratoriossa tehtyjen idätyskokeiden sekä pellolla tehtyjen havaintojen nojalla.

Tutkimuksen perusteella pääteltiin, että sään suomat edellytykset viljan kosteuden alentumiselle leikkuupuintia ajatellen ovat sitä paremmat, mitä aikaisemmin viljan tuleentuminen tapahtuu. Säätilaa, missä tähkäidäntä on mahdollista, esiintyy tavallisimmin elo-syyskuun aikana. Yleisintä tämä on Helsingin seuduilla elokuun 20. päivän ja syyskuun 10. päivän välillä, joskaan se ei ole ratkaisevasti vähäisempää näiden kuukausien muinakaan ajankohtina. Vaasan ja Kajaanin tienoilla lienee tähkäidäntä harvoin mahdollista enää syyskuun jälkipuoliskolla. 